\title{
High copper concentrations produce genotoxicity and cytotoxicity in bovine cumulus cells
}

\author{
Juan Mateo Anchordoquy ${ }^{1,2}$. Juan Patricio Anchordoquy ${ }^{1,2}$ • Noelia Nikoloff ${ }^{1}$. \\ Ana M Pascua ${ }^{1} \cdot$ Cecilia C Furnus ${ }^{1,3}$
}

Received: 11 January 2017 / Accepted: 29 June 2017

(C) Springer-Verlag GmbH Germany 2017

\begin{abstract}
The aim of this study was to investigate the cytotoxic and genotoxic effects of high copper $(\mathrm{Cu})$ concentrations on bovine cumulus cells (CCs) cultured in vitro. We evaluated the effect of $0,120,240$, and $360 \mu \mathrm{g} / \mathrm{dL} \mathrm{Cu}$ added to in vitro maturation (IVM) medium on CC viability assessed by the trypan blue (TB)-fluorescein diacetate (FDA) and 3-(4,5-dimethyl-2-thiazolyl)-2,5-diphenyl-2H-tetrazolium bromide (MTT) assays, apoptosis, and DNA damage. Differences in cell viability assessed by TB-FDA were not significant among $\mathrm{CC}$ treated with $0,120,240$, and $360 \mu \mathrm{g} / \mathrm{dL} \mathrm{Cu}$. However, mitochondrial activity assessed by MTT was lower in CC cultured with 120,240 , and $360 \mu \mathrm{g} / \mathrm{dL} \mathrm{Cu}$ as compared with the control $(p<0.01)$. Percentages of apoptotic cells were higher when CCs were treated with 120, 240, and $360 \mu \mathrm{g} /$ $\mathrm{dL} \mathrm{Cu}(p<0.05)$ due to higher frequencies of late apoptotic cells $(p<0.05)$. The frequency of live cells diminished in a dose-dependent manner when $\mathrm{Cu}$ was added to the culture medium. Whereas genetic damage index (GDI) increased significantly in CC cultured in the presence of 240 and $360 \mu \mathrm{g} /$ $\mathrm{dL} \mathrm{Cu}(p<0.05)$, DNA damage increased at all $\mathrm{Cu}$
\end{abstract}

Responsible editor: Philippe Garrigues

Cecilia C Furnus

cfurnus@fcv.unlp.edu.ar

1 IGEVET - Instituto de Genética Veterinaria "Prof. Fernando N. Dulout" (UNLP-CONICET LA PLATA), Facultad de Ciencias Veterinarias, Universidad Nacional de La Plata, calle 60 y $118 \mathrm{~s} / \mathrm{n}$, 1900 La Plata, Buenos Aires, Argentina

2 Cátedra de Fisiología, Laboratorio de Nutrición Mineral, Facultad de Ciencias Veterinarias, Universidad Nacional de La Plata, calle 60 y 118 s/n, 1900 La Plata, Buenos Aires, Argentina

3 Cátedra de Citología, Histología y Embriología “A," Facultad de Ciencias Médicas, Universidad Nacional de La Plata, calle 60 y 120 s/n, 1900 La Plata, Buenos Aires, Argentina concentrations tested $(p<0.05)$. These results indicate that $\mathrm{Cu}$ induces cytotoxic and genotoxic effects in bovine $\mathrm{CC}$.

Keywords Cumulus cells · MTT · Apoptosis · Comet assay · Copper

\section{Introduction}

Environmental quality plays an important role in human health. One quarter of global diseases are associated with environmental factors such as the presence of heavy metals (Rzymski et al. 2015). Healthy environments can decrease morbidity rate in humans (WHO 2006). Although several metals, such as chromium, manganese, zinc, and copper $(\mathrm{Cu})$, are essential for living in small quantities, they are toxic at high concentrations. The sources of global contamination by heavy metals include industry, transport, waste management, and soil fertilizers (Fenga 2016). In the environment, emission of heavy metals can pollute the atmosphere by combustion; oceans, rivers and soil by direct deposition; and thereby crops and other organisms through the food chain (Fenga 2016). Heavy metals mainly bioconcentrate in tissues and body fluids (Taupeau et al. 2001; Choi et al. 2007). They have been detected in follicular fluid (FF) of women (Younglai et al. 2002; Tolunay et al. 2016), sheep (Bires et al. 1995), and bovine (Picco et al. 2012). In mammals, certain pollutants contribute to the underlying causes of fertility problems (Kamarianos et al. 2003; Campagna et al. 2009). Exposure to lead and cadmium produce follicular atresia and early luteinization in cattle, and the presence of these metals in cervical mucus is toxic to spermatozoa (Rob and Dolezalova 1986). Previous studies have demonstrated that heavy metal exposure during in vitro maturation (IVM) affects oocyte maturation and causes chromosomal aberrations in bovine (Rodriguez-Tellez et al. 2005). Moreover, Leoni et al. (2002) found a negative effect of 
heavy metals on oocyte maturation and subsequent fertilization competence in ovine.

$\mathrm{Cu}$ plays an important role in mammalian cells as a cofactor of metabolic enzymes involved in radical detoxification, iron metabolism, and other physiological processes (Petris et al. 2000; Steveson et al. 2003; Lutsenko et al. 2007). However, the same redox properties that make $\mathrm{Cu}$ an essential micronutrient also contribute to its toxicity. Since $\mathrm{Cu}$ is a transition metal, it can enhance the production of reactive oxygen species (ROS) through the Fenton reaction (Lovejoy and Guillemin 2014). $\mathrm{Cu}$ has the capacity to produce oxidative damage in cells, interfering with essential cellular processes such as protein synthesis, membrane permeability, DNA structure, enzyme activities, essential ion functions, and respiration (Yruela 2005; Gratão et al. 2005).

Numerous layers of cumulus cells (CCs) surround the mammalian oocytes (Eppig 1991; Gilchrist et al. 2008). Their role in oocyte maturation, ovulation, and fertilization has been widely studied (Heller et al. 1981; Herlands and Schultz 1984; Camaioni et al. 1993; Sutton et al. 2003; Gilchrist et al. 2008; Lonergan and Fair 2008; Nagyova et al. 2012). CCs are closely related to the oocyte by gap junctions, providing nutrients and regulatory molecules. In addition, CCs play a key role in oocyte competence acquisition for subsequent development (Luciano et al. 2005; Ge et al. 2008). CC damage produces low fertilization and blastocyst rates, even in humans (Høst et al. 2002; Seino et al. 2002; Corn et al. 2005).

Fertility problems are an important human health issue (Evers 2002; Snijder et al. 2012). Bovine is a widely held experimental model for studying mechanisms and properties related to ovarian function in humans owing to physiological and structural similarities between both species biological systems (Babaei et al. 2012; Santos et al. 2014; Ceko et al. 2015). The aim of this study was to investigate the effect of high $\mathrm{Cu}$ concentrations on bovine $\mathrm{CC}$ cultured in vitro. For this purpose, experiments were designed to evaluate the effect of 0 , 120, 240, and $360 \mu \mathrm{g} / \mathrm{dL} \mathrm{Cu}$ added to IVM medium on CC viability, apoptosis, and DNA damage.

\section{Materials and methods}

All reagents for media preparation were purchased from Sigma Chemical Co. (Sigma-Aldrich, St. Louis, MO, USA). The maturation medium was bicarbonate-buffered TCM-199 supplemented with $10 \%(v / v)$ FCS, $0.2 \mathrm{mM}$ sodium pyruvate, $1 \mathrm{mM}$ glutamine, $1 \mathrm{mg} / \mathrm{mL}$ FSH, $1 \mathrm{mg} / \mathrm{mL} 17 \beta$-estradiol, and $50 \mathrm{mg} / \mathrm{mL}$ kanamycin. Standard aqueous copper sulfate solution was purchased from Merck (Tokyo, Japan). The Cu concentrations used (120, 240, and $360 \mu \mathrm{g} / \mathrm{dL} \mathrm{Cu})$ were higher than normal plasma $\mathrm{Cu}$ concentrations in bovine. $\mathrm{Cu}$ status in cattle is defined as deficient, marginal, and adequate at plasma
Cu concentrations of $<30,31-60$, and $>60 \mu \mathrm{g} / \mathrm{dL}$, respectively (Underwood and Suttle 1999).

\section{COCs}

Bovine ovaries were obtained from an abattoir and transported to the laboratory in sterile $\mathrm{NaCl}$ solution $(9 \mathrm{~g} / \mathrm{L})$ with antibiotics (streptomycin and penicillin) at $37{ }^{\circ} \mathrm{C}$ within $3 \mathrm{~h}$ after slaughter. Ovaries were pooled, regardless of the estrous cycle stage of the donor. Cumulus cell-oocyte complexes (COCs) were aspirated from 3 to $8 \mathrm{~mm}$ follicles, using an 18-G needle connected to a sterile syringe. Only intact COC with evenly granulated cytoplasm were selected for IVM, using a low power $(\times 20-\times 30)$ stereomicroscope (Nikon, Tokyo, Japan).

\section{IVM and CC samples}

COCs were washed twice in TCM-199 buffered with $15 \mathrm{mM}$ HEPES and IVM medium. Groups of 10 COCs were transferred into $50 \mu \mathrm{L}$ of IVM medium under mineral oil (Squibb, Princeton, NJ, USA) pre-equilibrated in a $\mathrm{CO}_{2}$ incubator. Incubations were performed at $39{ }^{\circ} \mathrm{C}$ in an atmosphere of $5 \% \mathrm{CO}_{2}$ in air with saturated humidity for $24 \mathrm{~h}$. At the end of IVM, CCs from each treatment were obtained from COCs by repeated pipetting with a narrow-bore glass pipette in TCM-199 buffered with HEPES, and washed three times in calcium- and magnesium-free PBS containing $1 \mathrm{mg} / \mathrm{mL}$ PVP.

\section{CC viability by the TB-FDA technique}

After IVM of COCs, CC viability was evaluated. For this purpose, CCs were incubated for $10 \mathrm{~min}$ at $37{ }^{\circ} \mathrm{C}$ in PBS medium with $2.5 \mu \mathrm{g} / \mathrm{L}$ fluorescein diacetate fluorochrome and $2.5 \mathrm{~g} / \mathrm{L}$ trypan blue. Then, CCs were washed in PBS and observed in a Nikon Optiphot epifluorescence microscope (Nikon, Tokyo, Japan) equipped with a 330-490 nm excitation filter and 420-520 nm emission filter at $\times 100$ magnification. Live CCs were visible in green fluorescence, whereas dead ones showed a characteristic blue staining under white light (Hoppe and Bavister 1984).

\section{MTT assay}

The MTT assay evaluates the respiratory activity of the mitochondrial succinate-tetrazolium reductase system, which converts the yellow tetrazolium salt into a blue formazan dye (Robb et al. 1990). Since the conversion takes place in living cells, the amount of formazan produced is directly correlated with the number of viable cells. The MTT assay was performed following the protocol of $\mathrm{Wu}$ et al. (2013). Briefly, $1 \times 10^{4} \mathrm{CCs} /$ well was cultured in TCM-199 on 96-well microplates for 4 days until the cells were nearly confluent. Afterwards, the culture medium was removed, and CCs were 
treated with $0,120,240$ and $360 \mu \mathrm{g} / \mathrm{dL} \mathrm{Cu}$ dissolved in $100 \mu \mathrm{l}$ TCM-199 for further $24 \mathrm{~h}$. Ethanol was used as positive control. MTT was added to each well at a final concentration of $0.25 \mathrm{mg} / \mathrm{mL}$, and incubated at $37{ }^{\circ} \mathrm{C}$ for $3 \mathrm{~h}$. Afterwards, $100 \mu \mathrm{L}$ dimethyl sulfoxide (DMSO) was added to dissolve formazan blue crystals. Absorbance at $490 \mathrm{~nm}$ was measured by a microplate spectrophotometer (Biotek Instruments Inc., Bedfordshire, UK). Data were normalized to measurements from control cultures which were considered $100 \%$ cell survival.

\section{Apoptosis detection by annexin $\mathrm{V}$-affinity assay}

Apoptosis was evaluated by membrane redistribution of phosphatidylserine with the Annexin V-FLUOS Staining Kit (cat no. 11-858-777-001; Roche Diagnostics GmbH, Roche Applied Science, Penzberg, Germany). The assay involves simultaneous staining with both Annexin V-FLUOS (green) and the DNA stain propidium iodide (PI, red). Intact cells exclude PI and Annexin V-FLUOS. CCs were classified following the criteria reported by Pläsier et al. (1999) as live (annexin V negative/PI negative), early-apoptotic (annexin $\mathrm{V}$ positive/PI negative), late-apoptotic (annexin $\mathrm{V}$ positive/PI positive), and necrotic (annexin V negative/PI positive) cells. Briefly, at the end of IVM, CCs were washed twice with PBS and centrifuged at $200 \times g$ for $5 \mathrm{~min}$. Then, the pellet was resuspended in $100 \mu \mathrm{L}$ of annexin V-FLUOS labeling solution and incubated in the dark for $10-15 \mathrm{~min}$ at $15-25^{\circ} \mathrm{C}$. Cells were analyzed under a fluorescence microscope (Nikon, Tokyo, Japan).

\section{Comet assay}

CC samples were processed by single cell gel electrophoresis (SCGE) using the alkaline version described by Singh et al. (1988) with modifications (Tice and Strauss 1995). Briefly, slides were covered with a layer of $180 \mu \mathrm{L}$ of $0.5 \%$ normal agarose (Carlsbad, CA, USA). Then, $75 \mu \mathrm{L}$ of $0.5 \%$ low melting point agarose (Carlsbad) was mixed with cells and layered onto the slides, which were immediately covered with cover slips. After agarose solidification at $48{ }^{\circ} \mathrm{C}$ for $10 \mathrm{~min}$, cover slips were removed and slides were immersed overnight at $48{ }^{\circ} \mathrm{C}$ in fresh lysis solution. The slides were equilibrated in alkaline solution for $20 \mathrm{~min}$. Electrophoresis was done for $30 \mathrm{~min}$ at $25 \mathrm{~V}$ and $300 \mathrm{~mA}(1.25 \mathrm{~V} / \mathrm{cm})$. Thereafter, slides were neutralized by washing ( 5 min each) three times with TRIS buffer ( $\mathrm{pH} 7.5$ ), and then with distilled water. Slides were stained with $1 / 1000$ SYBR Green I (Molecular Probes, Eugene, OR, USA) solution (Olive et al. 1999). Scoring was made at $\times 400$ magnification using a fluorescence microscope (Olympus BX40) equipped with a 515- to 560-nm excitation filter. Based on the extent of strand breakage, cells were classified according to their tail length into five categories, ranging from grade 0 (no visible tail), grade 1 (comets with tiny tail), grade 2 (comets with a dim tail), grade 3 (comets with a clear tail), to grade 4 (comets with a clear decrease in the diameter of the head and a clear tail). DNA damage expressed as arbitrary units was established according to Collins (2004). Results are expressed as the mean number of damaged nucleoids (sum of grades II, III, and IV) and the mean comet score for each treatment. The genetic damage index (GDI) of each treatment was obtained using the formula GDI $=[(\mathrm{I})+$ 2 (II) +3 (III) $+4(\mathrm{IV})] / \mathrm{N}(0-\mathrm{IV})$, where 0 -IV represent the nucleoid type, and N0-NIV represent the total number of nucleoids scored (Pitarque et al. 1999).

\section{Statistical analyses}

The SCGE data were compared by applying one-way ANOVA using Statgraphics 5.1 Plus software. Variables were tested for normality with the Kolmogorov-Smirnov test, and homogeneity of variances between groups was verified by the Levene's test. Pairwise comparisons between the different groups were made using the post hoc least significant difference test (LSD). Differences in GDI, viability, and apoptosis in treated and control cells were evaluated by $\chi^{2}$ test. The twotailed Student's $t$ test was used to compare MTT data between treated and control groups. The chosen level of significance was $p<0.05$ unless indicated otherwise.

\section{Experimental design}

\section{Assessment of $\mathrm{CC}$ viability with different $\mathrm{Cu}$ concentrations by the TB-FDA technique}

In Experiment 1, CC viability after $24 \mathrm{~h}$ IVM with $0,120,240$, and $360 \mu \mathrm{g} / \mathrm{dL} \mathrm{Cu}$ was evaluated as described above ("CC viability by the TB-FDA technique" section). For this purpose, 243 COCs were matured in three replicates (a separate batch of ovaries for each day). Each batch of COCs was processed for preparing slides to analyze at least 400 single CCs per treatment.

\section{Assessment of $\mathrm{CC}$ mitochondrial activity with different $\mathrm{Cu}$ concentrations by the MTT assay}

In Experiment 2, $\mathrm{CC}$ mitochondrial activity after $24 \mathrm{~h}$ of incubation with $0,120,240$, and $360 \mu \mathrm{g} / \mathrm{dL} \mathrm{Cu}$ was evaluated ("MTT assay" section). For this purpose, CCs were cultured in three independent replicates (a separate batch of ovaries for each day).

\section{Assessment of $\mathrm{CC}$ apoptosis with different $\mathrm{Cu}$ concentrations}

In Experiment 3, CC apoptosis after $24 \mathrm{~h} \mathrm{IVM} \mathrm{with} \mathrm{0,} \mathrm{120,}$ 240 , and $360 \mu \mathrm{g} / \mathrm{dL} \mathrm{Cu}$ was determined as described above 
("Apoptosis detection by annexin V-affinity assay" section). For this purpose, 246 COCs were matured in three replicates (a separate batch of ovaries for each day). At least 300 CCs were analyzed per treatment in each replicate.

\section{Assessment of CC DNA damage with different $\mathrm{Cu}$ concentrations}

In Experiment 4, DNA damage of $\mathrm{CC}$ following the addition of $0,120,240$, or $360 \mu \mathrm{g} / \mathrm{dL} \mathrm{Cu}$ to the IVM medium was measured by the comet assay. CCs were matured for $24 \mathrm{~h}$ (as described above) and, thereafter, DNA damage was measured. For this purpose, a total of 240 COCs in three replicates obtained on different days were matured in vitro. Each batch of COCs was processed for preparing slides to analyze at least 200 single CCs per treatment in each replicate.

\section{Results}

\section{Effect of $\mathrm{Cu}$ concentrations on $\mathrm{CC}$ viability by TB-FDA}

In Experiment 1, CC viability did not show significant differences among CCs treated with $0,120,240$, and $360 \mu \mathrm{g} / \mathrm{dL} \mathrm{Cu}$ concentrations during IVM $(89.8 \pm 0.31,87.1 \pm 0.34$, $88.0 \pm 0.33$, and $89.2 \pm 0.31 \%$, respectively; $p>0.05)$.

\section{Effect of $\mathrm{Cu}$ concentrations on $\mathrm{CC}$ mitochondrial activity}

In Experiment 2, the results demonstrated a significant depression in mitochondrial activity in ethanol-treated cultures (positive control, $52.91 \pm 6.68 \%$ ) as compared with the control $(p<0.001$; Fig. 1). Mitochondrial activity was significantly lower in $\mathrm{CC}$ cultured with $\mathrm{Cu}$ as compared with the control $(100 \pm 0,92.83 \pm 1.09,91.75 \pm 0.90,89.74 \pm 1.05 \%$ for $\mathrm{CC}$ exposed to $0,120,240$, and $360 \mu \mathrm{g} / \mathrm{dL} \mathrm{Cu}$, respectively; $p<0.01)$. No differences were found in $\mathrm{CC}$ mitochondrial activity when comparing $\mathrm{Cu}$ concentrations (Fig. 1).

\section{Effect of $\mathrm{Cu}$ concentrations on $\mathrm{CC}$ apoptosis}

Data for apoptosis in CC cultured for $24 \mathrm{~h}$ showed significant differences when comparing the percentages of apoptotic cells of control vs. positive control ( $p<0.001$; Table 1). The frequency of live cells diminished in a dose-dependent manner when $\mathrm{Cu}$ was added to culture medium (Table 1). Percentages of apoptotic cells were higher when CCs were treated with 120,240 , and $360 \mu \mathrm{g} / \mathrm{dL} \mathrm{Cu}(p<0.05)$ due to higher frequencies of late apoptotic cells $(p<0.05)$. Moreover, the addition of 240 and $360 \mu \mathrm{g} / \mathrm{dL} \mathrm{Cu}$ increased the frequency of necrotic cells $(p<0.05)$.

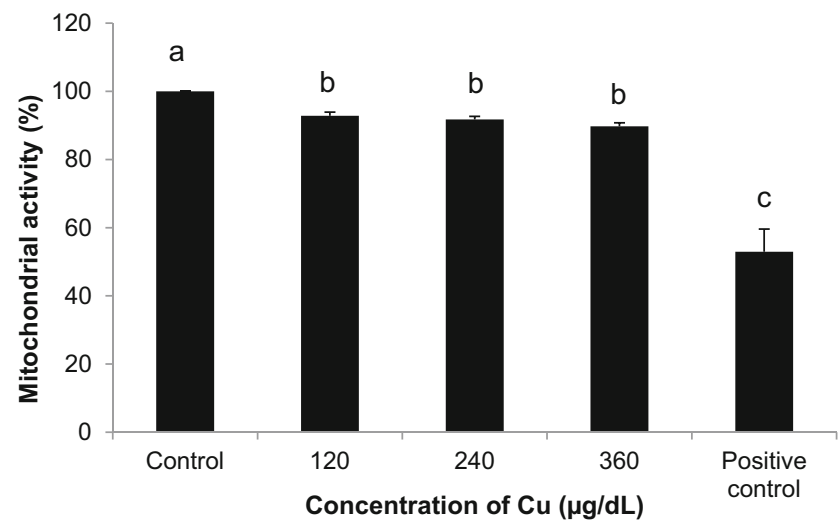

Fig. 1 Mitochondrial activity evaluated by MTT in bovine cumulus cells exposed to high copper concentrations for $24 \mathrm{~h}$. Bars with different letters statistically differ $(p<0.01)$. Cultures were incubated for $3 \mathrm{~h}$ with MTT after $24 \mathrm{~h}$ of $\mathrm{Cu}$ treatments. Results are expressed as the mean percentage \pm SEM of cell growth inhibition from three independent experiments. Five percent ethanol-treated cells were used as positive controls

\section{Effect of $\mathrm{Cu}$ concentrations on CC DNA damage}

In Experiment 4, $1 \mu \mathrm{g} / \mathrm{mL}$ bleomycin (positive control) induced an increase in damaged cell frequency and GDI as compared with the control $(p<0.01)$. GDI increased significantly in CC cultured in the presence of 240 and $360 \mu \mathrm{g} / \mathrm{dL}$ $\mathrm{Cu}$ during IVM ( $p<0.05$; Table 2$)$. DNA damage (grades II, III, and IV) increased with all $\mathrm{Cu}$ concentrations $(p<0.05$; Table 2). We observed that such increase was due to the existence of higher type III and IV cells $(p<0.05)$.

\section{Discussion}

In the present study, we evaluated the effect of high $\mathrm{Cu}$ concentrations during bovine $\mathrm{COC}$ maturation. $\mathrm{CC}$ viability was assessed by the TB-FDA and MTT assays; apoptosis and comet assay results were used to determine whether treatment with high $\mathrm{Cu}$ concentrations could induce cytotoxicity and genotoxicity. Our study demonstrated that $\mathrm{Cu}$ supplementation to IVM medium (I) did not modify cell viability by the TB-FDA technique, (II) decreased mitochondrial activity, (III) increased apoptosis, and (IV) increased DNA damage in bovine $\mathrm{CC}$. These results indicate that exposure of bovine $\mathrm{CC}$ to high $\mathrm{Cu}$ concentrations during COC IVM generates genotoxic and cytotoxic effects.

$\mathrm{Cu}$ is an essential trace element and an integral part of many intracellular and extracellular Cu-dependent enzymes and structural proteins (Jazvinšćak Jembrek et al. 2014; Roychoudhury et al. 2014). $\mathrm{Cu}$ is involved in a number of biochemical and physiological functions (Jazvinšćak Jembrek et al. 2014; Roychoudhury et al. 2014) such as cellular respiration, iron oxidation, pigment production, neurotransmitter biosynthesis, antioxidant defense, and collagen synthesis (Nevitt et al. 2012; 
Table 1 Analysis of apoptosis in bovine cumulus cells exposed to high copper concentrations for $24 \mathrm{~h}$

\begin{tabular}{|c|c|c|c|c|c|}
\hline \multirow[t]{2}{*}{ Copper concentration } & \multirow[t]{2}{*}{ No. } & \multicolumn{4}{|c|}{ Percentage of cells $(\%)$} \\
\hline & & Alive & Early apoptotic & Late apoptotic & Necrotic \\
\hline Control & 1022 & $60.86 \pm 0.49 a$ & $1.56 \pm 0.12 \mathrm{a}$ & $5.38 \pm 0.22 \mathrm{a}$ & $12.62 \pm 0.32 \mathrm{a}$ \\
\hline $120 \mu \mathrm{g} / \mathrm{dL}$ & 1001 & $55.24 \pm 0.50 \mathrm{~b}$ & $2.59 \pm 0.16 a$ & $9.69 \pm 0.29 b$ & $12.48 \pm 0.32 \mathrm{a}$ \\
\hline $240 \mu \mathrm{g} / \mathrm{dL}$ & 1041 & $46.01 \pm 0.50 \mathrm{c}$ & $2.20 \pm 0.15 \mathrm{a}$ & $10.08 \pm 0.30 \mathrm{~b}$ & $22.47 \pm 0.41 b$ \\
\hline $360 \mu \mathrm{g} / \mathrm{dL}$ & 1035 & $41.64 \pm 0.50 \mathrm{~d}$ & $2.12 \pm 0.14 \mathrm{a}$ & $8.79 \pm 0.27 b$ & $28.11 \pm 0.45 \mathrm{c}$ \\
\hline Positive control & 1003 & $17.13 \pm 0.40 \mathrm{e}$ & $9.6 \pm 0.18 b$ & $55.7 \pm 0.61 \mathrm{c}$ & $18.30 \pm 0.47 b$ \\
\hline
\end{tabular}

Values with different lowercase letters within each column differ $(p<0.05)$. Bovine COCs were incubated in IVM medium alone (control); IVM + 120, 240, and $360 \mu \mathrm{g} / \mathrm{dL} \mathrm{Cu}$; and IVM + 5\% ETOH (positive control) during $24 \mathrm{~h}$. COCs were denuded and CC suspensions were exposed to annexin V-FITC-propidium iodide (PI). CCs were classified as live (annexin V negative/PI negative), early-apoptotic (annexin V positive/PI negative), lateapoptotic (annexin V positive/PI positive), and necrotic (annexin V negative/PI positive). Each experiment was repeated three times and samples were performed in duplicate for each experimental point. Results are presented as mean \pm SEM
Tchounwou et al. 2012; Jazvinšćak Jembrek et al. 2014). Cu is necessary for living organisms in small quantities, but toxic at higher concentrations (Nevitt et al. 2012). In physiological conditions, there are mechanisms that ensure adequate supplies of $\mathrm{Cu}$ ions preventing toxic effects (Rae et al. 1999; Kaplan and Lutsenko 2009). However, acute and chronic $\mathrm{Cu}$ excess can provoke cellular damage (Jazvinšćak Jembrek et al. 2014). Cu is present in natural ecosystems (Spatari et al. 2002). In addition, $\mathrm{Cu}$-containing substances are extensively used in industry, agriculture, medical, and home products, representing a growing biological hazard (Wang et al. 2013). The main artificial sources of $\mathrm{Cu}$ are non-ferrous metal mining, metal ore smelting, galvanization, oil and gasoline combustion, waste incineration, and excessive use of certain plant protectants (Georgopoulos et al. 2001; Miska-Schramm et al. 2014; Zhang et al. 2015).

Even though the negative effects of overexposure to $\mathrm{Cu}$ on different organs such as the lung, spleen, liver, kidney, and intestine are well known, there exists scarce information about the effects of $\mathrm{Cu}$ toxicities on female genital organs and their cells
(Minervino et al. 2009; Babaei et al. 2012; Tolunay et al. 2016). Our current observations reveal that $\mathrm{Cu}$ was able to induce an increase in the frequency of apoptotic bovine $\mathrm{CC}$ after $24 \mathrm{~h}$ of treatment by increasing late apoptotic cell percentages. Moreover, 240 and $360 \mu \mathrm{g} / \mathrm{dL} \mathrm{Cu}$ induced a strong increase in necrotic cell rates. Previous studies reported that $\mathrm{Cu}$ was one of the most potent metals in apoptosis cell induction (Formigari et al. 2013). It has been demonstrated that apoptosis rates are correlated with $\mathrm{Cu}$ excess in different cell types such as liver cells (Oe et al. 2016), mouse fibroblasts (Cao et al. 2012), osteoblasts (Cortizo et al. 2004), PC-3 human prostate cancer cells (Wang et al. 2014), and P19 neurons (Jazvinšćak Jembrek et al. 2014). This effect was observed in both in vivo and in vitro systems (Handy 2003; Lu et al. 2006; Yu et al. 2008; Wang et al. 2014; Zhong et al. 2015; Pramanik et al. 2016). However, molecular and cellular mechanisms that link $\mathrm{Cu}$ to programmed cell death remain largely unknown (Jazvinšćak Jembrek et al. 2014). Cu apoptotic potential is associated with its capacity to generate ROS through participation in the Haber-Weiss redox cycling

Table 2 Analysis of DNA damage by the comet assay in bovine cumulus cells after in vitro culture with different copper concentrations

\begin{tabular}{|c|c|c|c|c|c|c|c|}
\hline \multirow[t]{2}{*}{ Treatment } & \multicolumn{5}{|c|}{ Proportion of damaged nucleoids (\%) } & \multirow{2}{*}{$\begin{array}{l}\text { DNA damage }(\%) \\
(\mathrm{II}+\mathrm{III}+\mathrm{IV})\end{array}$} & \multirow[t]{2}{*}{ GDI } \\
\hline & 0 & I & II & III & IV & & \\
\hline Control & $82.52 \pm 0.37 \mathrm{a}$ & $7.36 \pm 0.26 \mathrm{a}$ & $6.86 \pm 0.24 a$ & $2.37 \pm 0.14 \mathrm{a}$ & $0.87 \pm 0.09 \mathrm{a}$ & $10.11 \pm 0.3 \mathrm{a}$ & $0.32 \pm 0.08 \mathrm{a}$ \\
\hline $120 \mu \mathrm{g} / \mathrm{dL} \mathrm{Cu}$ & $78.02 \pm 0.41 b$ & $5.55 \pm 0.22 \mathrm{a}$ & $8.02 \pm 0.27 \mathrm{a}$ & $4.44 \pm 0.20 b$ & $3.95 \pm 0.20 \mathrm{~b}$ & $16.62 \pm 0.3 b$ & $0.51 \pm 0.07 \mathrm{a}$ \\
\hline $240 \mu \mathrm{g} / \mathrm{dL} \mathrm{Cu}$ & $74.18 \pm 0.44 b c$ & $5.98 \pm 0.24 \mathrm{a}$ & $9.1 \pm 0.29 \mathrm{a}$ & $6.98 \pm 0.26 \mathrm{c}$ & $3.74 \pm 0.19 b$ & $19.82 \pm 0.4 b$ & $0.60 \pm 0.09 b$ \\
\hline $360 \mu \mathrm{g} / \mathrm{dL} \mathrm{Cu}$ & $73.25 \pm 0.44 c$ & $7.87 \pm 0.27 \mathrm{a}$ & $7.75 \pm 0.27 \mathrm{a}$ & $7.12 \pm 0.26 \mathrm{c}$ & $4.00 \pm 0.20 \mathrm{~b}$ & $18.85 \pm 0.3 b$ & $0.61 \pm 0.08 \mathrm{~b}$ \\
\hline Positive control & $48.54 \pm 0.42 \mathrm{~d}$ & $23.74 \pm 0.21 b$ & $18.14 \pm 0.29 b$ & $5.64 \pm 0.19 b$ & $3.78 \pm 0.19 b$ & $27.71 \pm 0.2 \mathrm{c}$ & $0.92 \pm 0.02 \mathrm{c}$ \\
\hline
\end{tabular}

Values with different lowercase letters within each column differ $(p<0.05)$. Bovine COCs were incubated in IVM medium alone (control); IVM + 120, 240 and $360 \mu \mathrm{g} / \mathrm{dL} \mathrm{Cu}$, and IVM $+1 \mu \mathrm{g} / \mathrm{mL}$ bleomycin (positive control) during $24 \mathrm{~h}$. DNA damage in CC was evaluated by SCGE in four replicates. The extent of DNA damage was quantified by the length of DNA migration (comet), which was visually determined in 200 randomly selected and nonoverlapping cells per replicate. DNA damage was classified into four classes: 0-I (undamaged), II (minimum damage), III (medium damage), and V (maximum damage). Results are expressed as mean comet score for each treatment group and mean damaged nucleoids (sum of classes II, III, and IV). Genetic damage index (GDI) of each treatment was determined with the formula GDI $=[(\mathrm{I})+2(\mathrm{II})+3(\mathrm{III})+4(\mathrm{IV})] / \mathrm{N}(0-\mathrm{IV})$, where $0-\mathrm{IV}$ represent the nucleoid type, and N0-NIV the total number of nucleoids scored. Results are presented as mean \pm SEM 
as well as the inhibition of complex I of the electron transport chain, the main source of intracellular ROS (Pourahmad and O'Brien 2000; Formigari et al. 2013). Previous studies using peripheral blood lymphocytes provide evidence that $\mathrm{Cu}$ produces apoptosis by $\mathrm{H}_{2} \mathrm{O}_{2}$ and hydroxyl radical generation, resulting in mitochondrial depolarization, caspase-3 activation, and nuclear fragmentation (Jiménez Del Río and Vélez-Pardo 2004; Formigari et al. 2013). Intracellular ROS production activates and modulates apoptosis by regulating p 53 activity in certain cell types (Narayanan et al. 2001; VanLandingham et al. 2002), but not in others (Jiménez Del Río and Vélez-Pardo 2004). Although $\mathrm{Cu}$ cell overexposure induces ROS formation, ROS do not appear to cause all $\mathrm{Cu}$-mediated DNA damage because $\mathrm{Cu}$ is mutagenic (Formigari et al. 2013).

Even though, we previously demonstrated that "adequate" $(60 \mu \mathrm{g} / \mathrm{dL}) \mathrm{Cu}$ concentration added to IVM medium decreased DNA damage and apoptosis in bovine cumulus cells (Rosa et al. 2016), we observed an increase of necrotic cell percentages when $\mathrm{Cu}$ was added at high concentrations to the culture medium in concordance with other authors (Aston et al. 2000; Krumschnabel et al. 2005). Cu excess might interact in a non-specific manner with several macromolecules either by modifying their conformation or by causing sitespecific damage that result in a disruption of vital cellular processes which further lead to apoptotic and necrotic cell death (Didenko et al. 2003; Krumschnabel et al. 2005; Rana 2008; Cao et al. 2012; Kuku et al. 2016; Philipp et al. 2016).

DNA damage can be an end-product of the apoptosis phenomenon or one of the factors for its progress (Wang 2001; Rana 2008). Recently, it has been reported that $\mathrm{Cu}$ accumulation causes apoptosis mediated by DNA damage (Roychoudhury et al. 2014). In the present study, the comet assay was used to analyze DNA damage in CCs incubated with $\mathrm{Cu}$. We demonstrated that $\mathrm{Cu}$ had a detrimental effect on DNA integrity of CC after $24 \mathrm{~h}$ of treatment with 120, 240, and $360 \mu \mathrm{g} / \mathrm{dL} \mathrm{Cu}$. These findings are in agreement with the genotoxic profile shown in other cellular systems. Addition of $\mathrm{Cu}$ to culture media produced DNA damage in C6 cells (Jazvinšćak Jembrek et al. 2014), neurons (Lévay et al. 1997; Nzengue et al. 2012), human peripheral blood mononuclear cells (Singh et al. 2006), HepG-2 cells (Liu et al. 2016), HeLa cells (Liu et al. 2016), and WIL2-NS human B lymphoblastoid cells (Alimba et al. 2016). The affinity of $\mathrm{Cu}$ for specific sites on double-stranded DNA is higher than that of other metals (Formigari et al. 2013). It is suggested that $\mathrm{Cu}$ bound to DNA reacts with $\mathrm{H}_{2} \mathrm{O}_{2}$ to generate hydroxyl radicals, which then attack the DNA bases in a site-specific manner (Aruoma et al. 1991). Therefore, $\mathrm{Cu}$ might be capable of inducing DNA strand breaks and oxidation of DNA bases (Gaetke and Chow 2003).

In the present study, $\mathrm{CCs}$ incubated with $\mathrm{Cu}$ concentrations resulted in a reduction of mitochondrial activity. The cytotoxicity analyzed by the MTT method was higher when CCs were cultured with 120,240 , and $360 \mu \mathrm{g} / \mathrm{dL} \mathrm{Cu}$. Our results are in agreement with those presented by Cao et al. (2012). Using the MTT assay, these authors found that supplementation with $\mathrm{Cu}(10,50,100,500,1000,2500,4000,5000$ and 10,000 $\mu \mathrm{g} /$ dL) resulted in a significant decrease in L929 fibroblast viability. Also, the accumulation of $\mathrm{Cu}$ oxide nanoparticles (CuO-NPs) in $\mathrm{C} 6$ glioma cells produces a severe loss in cell viability (assessed by MTT reduction and cellular lactate dehydrogenase activity) and cell membrane integrity (Joshi et al. 2016). Similar results have been observed when $\mathrm{Cu}$ chloride was used (Nzengue et al. 2012); also, HepG2 cell exposure to 10,200 , and $500 \mu \mathrm{M} \mathrm{Cu}$ sulfate for 8 or $24 \mathrm{~h}$ reduced the viability as compared with untreated cells (Liu et al. 2014). In the present study, loss in cellular MTT reduction capacity was observed for all $\mathrm{Cu}$ conditions, suggesting that the MTT assay is a more sensitive indicator of $\mathrm{Cu}$-induced cellular viability decrease than the TB-FDA assay.

To our knowledge, we have conducted the first genotoxic and cytotoxic evaluation of high $\mathrm{Cu}$ concentrations in bovine $\mathrm{CC}$ during COC IVM. As stated previously, our results revealed that $\mathrm{Cu}$ was able to induce genotoxicity and cytotoxicity in bovine female reproductive cells. Bovine ovary is a popular experimental model for studying mechanisms and properties related to ovarian function in humans (Babaei et al. 2012; Santos et al. 2014; Ceko et al. 2015). COC is the structural and functional unit present in mammalian antral follicles (Camaioni et al. 1993). COCs are embedded in FF, which is a type of blood plasma ultrafiltrate containing secretion from the ovarian follicle cells (Tolunay et al. 2016). Any change in FF may potentially affect $\mathrm{CC}$. It is interesting to point out that the lowest $\mathrm{Cu}$ concentration used in this study $(120 \mu \mathrm{g} / \mathrm{dL})$ is very close to that found in FF of bovine (59.9-110.8 $\mu \mathrm{g} / \mathrm{dL}$ ) (Picco et al. 2012) and women (65.8-123.8 $\mu \mathrm{g} / \mathrm{dL}$, Cavallini et al. 2016; and 33-177 $\mu \mathrm{g} / \mathrm{dL}$, Tolunay et al. 2016). CCs surround the oocyte during the maturation process within the follicle and protect the developing oocyte providing nutrients through gap junctions (Tatemoto et al. 2000; Fatehi et al. 2002). Any alteration or damage of these cells can impair the oocyte developmental capacity (Ikeda et al. 2003). In conclusion, the present study indicates that $\mathrm{Cu}$ induces a genotoxic and cytotoxic effect on bovine CC. In addition, our findings support the view that $\mathrm{CC}$ might be a sensitive cell model for the study of $\mathrm{Cu}$-induced genotoxicity and cytotoxicity.

Acknowledgements We are grateful to the staff of Frigorifico Gorina S.A. for providing the bovine ovaries. We also thank Adriana Di Maggio for manuscript correction.

\section{Compliance with ethical standards}

Funding This work was supported by grants from Agencia Nacional de Promoción Científica y Tecnológica de la República Argentina (PICT BID 1972-2013), Ministerio de Ciencia, Tecnología e Innovación Productiva de la Nación Argentina. 
Conflict of interest The authors declare that there are no conflicts of interest.

\section{References}

Alimba CG, Dhillon V, Bakare AA, Fenech (2016) Genotoxicity and cytotoxicity of chromium, copper, manganese and lead, and their mixture in WIL2-NS human B lymphoblastoid cells is enhanced by folate depletion. Mutat Res Genet Toxicol Environ Mutagen 98-799:35-47. doi:10.1016/j.mrgentox.2016.02.002

Aruoma OI, Halliwell B, Gajewski E, Dizdaroglu M (1991) Copperindependent damage to the bases in DNA in the presence of hydrogenperoxide. Biochem J 273:601-604

Aston NS, Watt N, Morton IE, Tanner MS, Evans GS (2000) Copper toxicity affects proliferation and viability of human hepatoma cells (HepG2 line). Hum Exp Toxicol 19(6):367-376

Babaei H, Roshangar L, Sakhaee E, Abshenas J, Kheirandish R, Dehghani R (2012) Ultrastructural and morphometrical changes of mice ovaries following experimentally induced copper poisoning. Iran Red Crescent Med J 14(9):558-568

Bires J, Maracek I, Bartko P, Biresova M, Weissova T (1995) Accumulation of trace elements in sheep and the effects upon qualitative and quantitative ovarian changes. Vet Hum Toxicol 37(4): 349-356

Camaioni A, Hascall VC, Yanagishita M, Salustri A (1993) Effects of exogenous hyaluronic acid and serum on matrix organization and stability in the mouse cumulus cell-oocyte complex. J Biol Chem 268(27):20473-20481

Campagna C, Guillemette C, Ayotte P, Bailey JL (2009) Effects of an environmentally relevant organochlorine mixture and a metabolized extract of this mixture on porcine sperm parameters in vitro. J Androl 30(3):317-324. doi:10.2164/jandrol.108.006478

Cao B, Zheng Y, Xi T, Zhang C, Song W, Burugapalli K, Yang H, Ma Y (2012) Concentration-dependent cytotoxicity of copper ions on mouse fibroblasts in vitro: effects of copper ion release from TCu380A vs TCu220C intra-uterine devices. Biomed Microdevices 14(4):709-720. doi:10.1007/s10544-012-9651-x

Cavallini A, Lippolis C, Vacca M, Nardelli C, Castegna A, Arnesano F, Carella N, Depalo R (2016) The effects of chronic lifelong activation of the AHR pathway by industrial chemical pollutants on female human reproduction. PLoS One 11(3):0152181. doi:10.1371/ journal.pone. 0152181

Ceko MJ, Hummitzsch K, Hatzirodos N, Rodgers RJ, Harris HH (2015) Quantitative elemental analysis of bovine ovarian follicles using Xray fluorescence imaging. Metallomics 7(5):828-836. doi:10.1039/ $\mathrm{c} 5 \mathrm{mt} 00035 \mathrm{a}$

Choi MJ, Kim SC, Kim AN, Kwon HB, Ahn RS (2007) Effect of endocrine disruptors on the oocyte maturation and ovulation in amphibians, Rana dybowskii. Integr Biosci 11:1-8

Collins AR (2004) The comet assay for DNA damage and repair: principles, applications, and limitations. Mol Biotechnol 26(3):249-261. doi:10.1385/MB:26:3:249

Corn CM, Hauser-Kronberger C, Moser M, Tews G, Ebner T (2005) Predictive value of cumulus cell apoptosis with regard to blastocyst development of corresponding gametes. Fertil Steril 84(3):627-633. doi:10.1016/j.fertnstert.2005.03.061

Cortizo MC, De Mele MFL, Cortizo AM (2004) Metallic dental material biocompatibility in osteoblastlike cells: correlation with metal ion release. Biol Trace Elem Res 100(2):151-168

Didenko VV, Ngo H, Baskin DS (2003) Early necrotic DNA degradation: presence of blunt-ended DNA breaks, $3^{\prime}$ and $5^{\prime}$ overhangs in apoptosis, but only $5^{\prime}$ overhangs in early necrosis. Am J Pathol 162(5): 1571-1578. doi:10.1016/S0002-9440(10)64291-5
Eppig JJ (1991) Intercommunication between mammalian oocytes and companion somatic cells. Bioassays 13:569-574. doi:10.1002/bies. 950131105

Evers JLH (2002) Female subfertility. Lancet (London, England) 360(9327):151-159. doi:10.1016/S0140-6736(02)09417-5

Fatehi AN, Zeinstra EC, Kooij RV, Colenbrander B, Bevers MM (2002) Effect of cumulus cell removal of in vitro matured bovine oocytes prior to in vitro fertilization on subsequent cleavage rate. Theriogenology 57(4):1347-1355

Fenga C (2016) Occupational exposure and risk of breast cancer. Biomed Rep 4(3):282-292. doi:10.3892/br.2016.575

Formigari A, Gregianin E, Irato P (2013) The effect of zinc and the role of p53 in copper-induced cellular stress responses. J Appl Toxicol JAT 33(7):527-536. doi:10.1002/jat.2854

Gaetke LM, Chow CK (2003) Copper toxicity, oxidative stress, and antioxidant nutrients. Toxicology 189(1-2):147-163

Ge L, Sui H-S, Lan G-C, Liu N, Wang J-Z, Tan J-H (2008) Coculture with cumulus cells improves maturation of mouse oocytes denuded of the cumulus oophorus: observations of nuclear and cytoplasmic events. Fertil Steril 90(6):2376-2388. doi:10.1016/j.fertnstert.2007. 10.054

Georgopoulos PG, Roy A, Yonone-Lioy MJ, Opiekun RE, Lioy PJ (2001) Environmental copper: its dynamics and human exposure issues. Journal of toxicology and environmental health. Part B Crit Rev 4(4):341-394. doi:10.1080/109374001753146207

Gilchrist RB, Lane M, Thompson JG (2008) Oocyte-secreted factors: regulators of cumulus cell function and oocyte quality. Hum Reprod Update 14:155-177. doi:10.1093/humupd/dmm040

Gratão PL, Polle A, Lea PJ, Azevedo RA (2005) Making the life of heavy metal-stressed plants a little easier. Funct Plant Biol 32:481-494

Handy RD (2003) Chronic effects of copper exposure versus endocrine toxicity: two sides of the same toxicological process?. Comparative biochemistry and physiology. Part A Mol Integr Physiol 135(1):2538

Heller D, Cahill D, Schultz R (1981) Biochemical studies of mammalian oogenesis: metabolic cooperativity between granulosa cells and growing. Dev Biol 84:455-464

Herlands R, Schultz R (1984) Regulation of mouse oocyte growth: probably nutritional role for intercellular communication between follicle cells and oocytes in oocyte growth. J Exp Zool 229:317-325

Hoppe R, Bavister B (1984) Evaluation of the fluorescein diacetate (FDA) vital dye viability test with hamster and bovine embryos. Anim Reprod Sci 6:323-325

Høst E, Gabrielsen A, Lindenberg S, Smidt-Jensen S (2002) Apoptosis in human cumulus cells in relation to zona pellucida thickness variation, maturation stage, and cleavage of the corresponding oocyte after intracytoplasmic sperm injection. Fertil Steril 77(3):511-515

Ikeda S, Imai H, Yamada M (2003) Apoptosis in cumulus cells during in vitro maturation of bovine cumulus-enclosed oocytes. Reproduction 125(3):369-376

Jazvinšćak Jembrek M, Vlainić J, Radovanović V, Erhardt J, Oršolić N (2014) Effects of copper overload in P19 neurons: impairment of glutathione redox homeostasis and crosstalk between caspase and calpain protease systems in ROS-induced apoptosis. Biometals An Int J Role Metal Ions Biol Biochem Med 27(6):1303-1322. doi:10. 1007/s10534-014-9792-x

Jiménez Del Río M, Vélez-Pardo C (2004) Transition metal-induced apoptosis in lymphocytes via hydroxyl radical generation, mitochondria dysfunction, and caspase-3 activation: an in vitro model for neurodegeneration. Arch Med Res 35(3):185-193. doi:10.1016/ j.arcmed.2004.01.001

Joshi A, Rastedt W, Faber K, Schultz AG, Bulcke F, Dringen R (2016) Uptake and toxicity of copper oxide nanoparticles in C6 Glioma cells. Neurochem Res. doi:10.1007/s11064-016-2020-Z

Kamarianos A, Karamanlis X, Theodosiadou E, Goulas P, Smokovitis A (2003) The presence of environmental pollutants in the semen of 
farm animals (bull, ram, goat, and boar). Reprod Toxicol (Elmsford, N.Y.) 17(4):439-445

Kaplan JH, Lutsenko S (2009) Copper transport in mammalian cells: special care for a metal with special needs. J Biol Chem 284: 25461-25465. doi:10.1074/jbc.R109.031286

Krumschnabel G, Manzl C, Berger C, Hofer B (2005) Oxidative stress, mitochondrial permeability transition, and cell death in $\mathrm{Cu}$-exposed trout hepatocytes. Toxicol Appl Pharmacol 209(1):62-73. doi:10. 1016/j.taap.2005.03.016

Kuku G, Saricam M, Akhatova F, Danilushkina A, Fakhrullin RF, Culha M (2016) Surface-enhanced Raman scattering to evaluate nanomaterial cytotoxicity on living cells. Anal Chem. doi:10.1021/ acs.analchem.6b02917

Leoni G, Bogliolo L, Deiana G, Berlinguer F, Rosati I, Pintus PP, Ledda S, Naitana S (2002) Influence of cadmium exposure on in vitro ovine gamete dysfunction. Reprod Toxicol (Elmsford, N.Y.) 16(4): 371-377

Lévay G, Ye Q, Bodell WJ (1997) Formation of DNA adducts and oxidative base damage by copper mediated oxidation of dopamine and 6-hydroxydopamine. Exp Neurol 146(2):570-574. doi:10.1006/ exnr.1997.6560

Liu Y, Yang H, Song Z, Gu S (2014) Copper excess in liver HepG2 cells interferes with apoptosis and lipid metabolic signaling at the protein level. Turk J Gastroenterol Off J Turk Soc Gastroent 25(Suppl 1): 116-121. doi:10.5152/tjg.2014.5064

Liu Y-H, Li A, Shao J, Xie C-Z, Song X-Q, Bao W-G, Xu JY (2016) Four $\mathrm{cu}$ (ii) complexes based on antitumor chelators: synthesis, structure, DNA binding/damage, HSA interaction and enhanced cytotoxicity. Dalton Trans (Cambridge, England: 2003) 45(19):8036-8049. doi: $10.1039 / \mathrm{c} 6 \mathrm{dt} 00451 \mathrm{~b}$

Lonergan P, Fair T (2008) In vitro-produced bovine embryos: dealing with the warts. Theriogenology 69:17-22. doi:10.1016/j. theriogenology.2007.09.007

Lovejoy DB, Guillemin GJ (2014) The potential for transition metalmediated neurodegeneration in amyotrophic lateral sclerosis. Front Aging Neurosci 6:173. doi:10.3389/fnagi.2014.00173

Lu J, Zheng Y-L, Wu D-M, Sun D-X, Shan Q, Fan S-H (2006) Trace amounts of copper induce neurotoxicity in the cholesterol-fed mice through apoptosis. FEBS Lett 580(28-29):6730-6740. doi:10.1016/ j.febslet.2006.10.072

Luciano AM, Lodde V, Beretta MS, Colleoni S, Lauria A, Modina S (2005) Developmental capability of denuded bovine oocyte in a co-culture system with intact cumulusoocyte complexes: role of cumulus cells, cyclic adenosine 3',5'-monophosphate, and glutathione. Mol Reprod Dev 71(3):389-397. doi:10.1002/mrd.20304

Lutsenko S, Barnes NL, Bartee MY, Dmitriev OY (2007) Function and regulation of human copper-transporting ATPases. Physiol Rev 87(3):1011-1046. doi:10.1152/physrev.00004.2006

Minervino AHH, Barrêto Júnior RA, Ferreira RNF, Rodrigues FAML, Headley SA, Mori CS, Ortolani EL (2009) Clinical observations of cattle and buffalos with experimentally induced chronic copper poisoning. Res Vet Sci 87(3):473-478. doi:10.1016/j.rvsc.2009.05.002

Miska-Schramm A, Kruczek M, Kapusta J (2014) Effect of copper exposure on reproductive ability in the bank vole (Myodes glareolus). Ecotoxicol (London, England) 23(8):1546-1554. doi:10.1007/ s10646-014-1295-6

Nagyova E, Scsukova S, Nemcova L, Mlynarcikova A, Yi YJ, Sutovsky M, Sutovsky P (2012) Inhibition of proteasomal proteolysis affects expression of extracellular matrix components and steroidogenesis in porcine oocyte-cumulus complex. Dom Anim Endocrinol 42:50 62. doi:10.1016/j.domaniend.2011.09.003

Narayanan VS, Fitch CA, Levenson CW (2001) Tumor suppressor protein p53 mRNA and subcellular localization are altered by changes in cellular copper in human Hep G2 cells. J Nut 131(5):1427-1432
Nevitt T, Ohrvik H, Thiele DJ (2012) Charting the travels of copper in eukaryotes from yeast to mammals. Biochim Bioph Acta 1823(9): 1580-1593. doi:10.1016/j.bbamcr.2012.02.011

Nzengue Y, Steiman R, Rachidi W, Favier A, Guiraud P (2012) Oxidative stress induced by cadmium in the C6 cell line: role of copper and zinc. Biol Trace Elem Res 146(3):410-419. doi:10.1007/s12011011-9265-9

Oe S, Miyagawa K, Honma Y, Harada M (2016) Copper induces hepatocyte injury due to the endoplasmic reticulum stress in cultured cells and patients with Wilson disease. Exp Cell Res. doi:10.1016/ j.yexcr.2016.08.003

Olive PL, Durand RE, Jackson SM, Le Riche JC, Luo C, Ma R, McLaren DB, Aquino-Parsons C, Thomson TA, Trotter T (1999) The comet assay in clinical practice. Acta Oncol 8:839-844

Petris MJ, Strausak D, Mercer JF (2000) The Menkes copper transporter is required for the activation of tyrosinase. Hum Mol Genet 9(19): $2845-2851$

Philipp S, Sosna J, Adam D (2016) Cancer and necroptosis: friend or foe? CMLS 73(11-12):2183-2193. doi:10.1007/s00018-016-2193-2

Picco SJ, Rosa DE, Anchordoquy JP, Anchordoquy JM, Seoane A, Mattioli A, Furnus CC (2012) Effects of copper sulphate concentrations during in vitro maturation of bovine oocytes. Theriogenology 77(2):373-381. doi:10.1016/j.theriogenology.2011.08.009

Pitarque M, Vaglenov A, Nosko M, Hirvonen A, Norppa H, Creus A, Marcos R (1999) Evaluation of DNA damage by the comet assay in shoe workers exposed to toluene and other organic solvents. Mut Res 441(1):115-127

Pläsier B, Lloyd DR, Paul GC, Thomas CR, Al-Rubeai M (1999) Automatic image analysis for quantification of apoptosis in animal cell culture by annexin-V affinity assay. J Immunol Meth 229(1-2): $81-95$

Pourahmad J, O'Brien PJ (2000) A comparison of hepatocyte cytotoxic mechanisms for $\mathrm{Cu} 2+$ and $\mathrm{Cd} 2+$. Toxicology 143:263-273

Pramanik A, Laha D, Dash SK, Chattopadhyay S, Roy S, Das DK, Pramanik P, Karmakar P (2016) An in-vivo study for targeted delivery of copper-organic complex to breast cancer using chitosan polymer nanoparticles. Mat Sci Eng C 68:327-337. doi:10.1016/j. msec.2016.05.014

Rae TD, Schmidt PJ, Pufahl RA, Culotta VC, O’Halloran TV (1999) Undetectable intracellular free copper: the requirement of a copper chaperone for superoxide dismutase. Science 284:805-808

Rana SVS (2008) Metals and apoptosis: recent developments. J Trace Elem Med Biol (GMS) 22(4):262-284. doi:10.1016/j.jtemb.2008. 08.002

Rob O, Dolezalova J (1986) The toxicity of genital secretions to spermatozoa and disorders of ovulation in cows. Biol Chem Zivocisne Vyroby Vet 22:122-126

Robb J, Norval M, Neill WA (1990) The use of tissue culture for the detection of mycotoxins. Lett Appl Microbiol 10(4):161-165

Rodriguez-Tellez BE, Marcano L, Villamediana-Monreal PC (2005) Effects of cadmium chloride exposure on in vitro maturation of bovine oocytes. Rev Cient 15:443-450

Rosa DE, Anchordoquy JM, Anchordoquy JP, Sirini MA, Testa JA, Mattioli GA, Furnus CC (2016) Analyses of apoptosis and DNA damage in bovine cumulus cells after in vitro maturation with different copper concentrations: consequences on early embryo development. Zygote 24(6):869-879

Roychoudhury S, Bulla J, Sirotkin AV, Kolesarova A (2014) In vitro changes in porcine ovarian granulosa cells induced by copper. J Environ Sci Health Part A Toxic/Hazardous Subst Environ Eng 49(6):625-633. doi:10.1080/10934529.2014.865404

Rzymski P, Tomczyk K, Rzymski P, Poniedziałek P, Opala T, Wilczak M (2015) Impact of heavy metals on the female reproductive system. Ann Agri Environm Med AAEM 22(2):259-264. doi:10.5604/ 12321966.1152077 
Santos RR, Schoevers EJ, Roelen BA (2014) Usefulness of bovine and porcine IVM/IVF models for reproductive toxicology. Reprod Biol Endocrinol: RB\&E 12:117. doi:10.1186/1477-7827-12-117

Seino T, Saito H, Kaneko T, Takahashi T, Kawachiya S, Kurachi H (2002) Eight-hydroxy-2'-deoxyguanosine in granulosa cells is correlated with the quality of oocytes and embryos in an in vitro fertilization-embryo transfer program. Fertil Steril 77(6):1184-1190

Singh NP, McCoy MT, Tice RR, Schneider EL (1988) A simple technique for quantitation of low levels of DNA damage in individual cells. Exp Cell Res 175(1):184-191

Singh RP, Kumar S, Nada R, Prasad R (2006) Evaluation of copper toxicity in isolated human peripheral blood mononuclear cells and it's attenuation by zinc: ex vivo. Mol Cell Biochem 282(1-2):13-21. doi:10.1007/s11010-006-1168-2

Snijder CA, te Velde E, Roeleveld N, Burdorf A (2012) Occupational exposure to chemical substances and time to pregnancy: a systematic review. Hum Reprod Upd 18(3):284-300. doi:10.1093/ humupd/dms005

Spatari S, Bertram M, Fuse K, Graedel TE, Rechberger H (2002) The contemporary European copper cycle: 1 year stocks and flows. Ecol Econ 42:27-42

Steveson TC, Ciccotosto GD, Ma X-M, Mueller GP, Mains RE, Eipper BA (2003) Menkes protein contributes to the function of peptidylglycine alpha-amidating monooxygenase. Endocrinol 144(1):188-200. doi:10.1210/en.2002-220716

Sutton ML, Gilchrist RB, Thompson JG (2003) Effects of in-vivo and invitro environments on the metabolism of the cumulus-oocyte complex and its influence on oocyte developmental capacity. Hum Reprod Update 9:35-48

Tatemoto H, Sakurai N, Muto N (2000) Protection of porcine oocytes against apoptotic cell death caused by oxidative stress during in vitro maturation: role of cumulus cells. Biol Reprod 63(3):805-810

Taupeau C, Poupon J, Nomé F, Lefèvre B (2001) Lead accumulation in the mouse ovary after treatment-induced follicular atresia. Reprod Toxicol (Elmsford, N.Y.) 15(4):385-391

Tchounwou PB, Yedjou CG, Patlolla AK, Sutton DJ (2012) Heavy metal toxicity and the environment. EXS 101:133-164. doi:10.1007/9783-7643-8340-4 6

Tice RR, Strauss GH (1995) The single cell gel electrophoresis/comet assay: a potential tool for detecting radiation-induced DNA damage in humans. Stem Cells (Dayton, Ohio) 13(Suppl 1):207-214

Tolunay HE, Șükür YE, Ozkavukcu S, Seval MM, Ateș C, Türksoy VA, Ecemiș T, Atabekoğlu CS, Özmen B, Berker B, Sönmezer M (2016)
Heavy metal and trace element concentrations in blood and follicular fluid affect ART outcome. Eur J Obst Gynecol Reprod Biol 198: 73-77. doi:10.1016/j.ejogrb.2016.01.001

Underwood EJ, Suttle NF (1999) The mineral nutrition of livestock. CABI Publishing, London

VanLandingham JW, Fitch CA, Levenson CW (2002) Zinc inhibits the nuclear translocation of the tumor suppressor protein $\mathrm{p} 53$ and protects cultured human neurons from copper-induced neurotoxicity. NeuroMolecular Med 1(3):171-182. doi:10.1385/NMM:1:3:171

Wang JY (2001) DNA damage and apoptosis. Cell Death Diff 8(11): 1047-1048. doi:10.1038/sj.cdd.4400938

Wang L, Espinoza HM, Gallagher EP (2013) Brief exposure to copper induces apoptosis and alters mediators of olfactory signal transduction in coho salmon. Chemosphere 93:2639-2643. doi:10.1016/j. chemosphere.2013.08.044

Wang Y, Zeng S, Lin T-M, Krugner-Higby L, Lyman D, Steffen D, Xiong MP (2014) Evaluating the anticancer properties of liposomal copper in a nude xenograft mouse model of human prostate cancer: formulation, in vitro, in vivo, histology and tissue distribution studies. Pharm Res 31(11):3106-3119. doi:10.1007/s11095-014-1403-6

World Health Organization (WHO) (2006) Preventing disease through healthy environments. WHO, Geneva

Wu J, Tu D, Yuan L-Y, Yuan H, Wen L-X (2013) T-2 toxin exposure induces apoptosis in rat ovarian granulosa cells through oxidative stress. Environ Toxicol Pharmacol 36(2):493-500. doi:10.1016/j. etap. 2013.03.017

Younglai EV, Foster WG, Hughes EG, Trim K, Jarrell JF (2002) Levels of environmental contaminants in human follicular fluid, serum, and seminal plasma of couples undergoing in vitro fertilization. Arch Environ Contam Toxicol 43(1):121-126. doi:10.1007/s00244-0010048-8

Yruela I (2005) Copper in plants. Braz J Plant Physiol 171:145-156

Yu W-R, Jiang H, Wang J, Xie J-X (2008) Copper (Cu2+) induces degeneration of dopaminergic neurons in the nigrostriatal system of rats. Neurosci Bull 24(2):73-78. doi:10.1007/s12264-008-0073-y

Zhang L, Yang J, Cai Z, Yuan Z (2015) Understanding the spatial and temporal patterns of copper in-use stocks in China. Environ Sci Technol 49(11):6430-6437. doi:10.1021/acs.est.5b00917

Zhong L, Wang L, Xu L, Liu Q, Jiang L, Zhi Y, Lu W, Zhou P (2015) The role of NOS-mediated ROS accumulation in an early phase $\mathrm{Cu}-$ induced acute cytotoxicity in MCF-7 cells. Biometals 28(1):113122. doi:10.1007/s10534-014-9807-7 